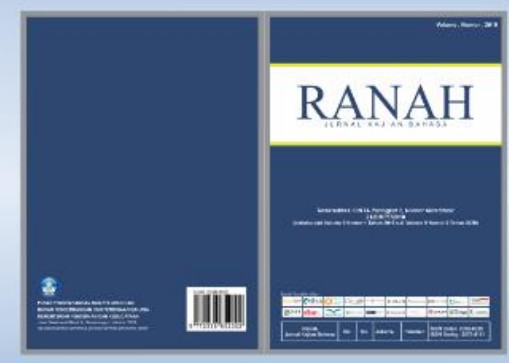

\title{
K-MEDOIDS CLUSTERING UNTUK PEMBENTUKAN DATABASE STOPWORD BAHASA JAWA
}

K-Medoids Clustering for the Establishment of Javanese Language Stopword Database

\author{
Aji Prasetya Wibawa, Farid Miftahuddin dan Suyono \\ Universitas Negeri Malang \\ Jalan Semarang No.5, Sumbersari, Kec. Lowokwaru, Kota Malang, Jawa Timur, Indonesia \\ aji.prasetya.ft@um.ac.id
}

Naskah Diterima Tanggal 23 September 2019-Direvisi Akhir Tanggal 26 April 2021—Disetujui Tanggal 1 Desember 2021 doi: https://doi.org/10.26499/rnh/v9i2.1490

\begin{abstract}
Abstrak
Stopword merupakan kata yang bisa diabaikan dalam permrosesan bahasa alami. Proses penghapusan kata ini ini tidak mempengaruhi proses analisis teks. Teknik yang digunakan untuk menghapus stopword disebut Stopword Removal. Teknik ini mencocokkan kata dengan daftar stopword (stoplist). Apabila kata tersebut terdapat pada daftar maka akan dihapus. Bahasa jawa sampai saat ini masih memiliki daftar stopword yang terbatas. Penelitian ini bertujuan membentuk daftar stopword menggunakan teknik cluster yakni K-medoids clustering. Teknik ini mengelompokkan kata berdasarkan kemunculan dalam teks bahasa Jawa. Dalam penerapannya, metode yang digunakan dalam penelitian ini terdiri dari lima tahap. Tahapan penelitian tersebut dimulai dari pengumpulan dataset, preprocessing data, clustering, dan terakhir adalah evaluasi. Setiap hasil cluster diuji dengan mencocokkannya dengan stopword hasil identifikasi ahli bahasa Jawa. Hasil penelitian ini menunujkkan bahwa stopword yang dihasilkan $k$ medoids clustering dengan nilai $\mathrm{K}=13$ yang memiliki akurasi sebesar 70,5\%.
\end{abstract}

Kata-kata kunci: stopword, bahasa Jawa, K-medoids, clustering

\begin{abstract}
Stopword is a word that can be ignored in the natural language process. This word removal process does not affect the text analysis process. The technique used to remove stopword is called Stopword Removal. This technique matches words to a stopword list. If the word is in the list it will be deleted. Javanese language to date still has a limited list of stopword. This study aims to form a list of stopword using cluster techniques namely K-medoids clustering. This technique groups words by occurrence in Javanese text. Each cluster result is tested by matching it with a stopword of javanese expert identification. The results of this study suggest that the stopword produced by k-medoids clustering with a value of $K=13$ has an accuracy of $70.5 \%$.
\end{abstract}

Keywords: stopword, Javanese Language, K-medoids, clustering

How to Cite: Wibawa, Aji Prasetya, dkk. (2021). K-Medoids Clustering untuk Pembentukan Database Stopword Bahasa Jawa. Ranah: Jurnal Kajian Bahasa. 10(2). 261-269. Doi: https://doi.org/10.26499/rnh/v9i2.1490

\section{PENDAHULUAN}

Bahasa Jawa merupakan salah satu bahasa Austronesia, yang termasuk dalam subkelompok Melayu-Polinesia Barat dan rumpun Sunda. Sesuai dengan anggota subkelompok lainnya, kebanyakan akar kata Jawa terdiri dari dua suku kata, dan dari varian tata bahasa ini diucapkan melalui imbuhan (Oakes, 2016). Bahasa Jawa merupakan bahasa pergaulan sehari-hari di 
daerah Jawa, yang digunakan untuk berinteraksi antar individu dan memungkinkan terjadinya komunikasi dan perpindahan informasi. Tidak hanya di wilayah pulau Jawa dan Indonesia, bahasa Jawa juga digunakan pada daerah lain, seperti Sumatera, Kalimantan, Sulawesi, dan pulau lainnya di Indonesia, serta di luar negeri seperti Suriname, Kaledonia Baru, dan kampung Jawa di Malaysia (Saddhono \& Hartanto, 2021).

Dari latar belakang tersebut, bahasa Jawa merupakan salah satu warisan budaya Indonesia yang harus dilestarikan dan dijaga (Kridalaksana, 2001). Berdasarkan survey pada tahun 2021, Bahasa Jawa merupakan bahasa yang digunakan oleh sekitar 68 juta orang di seluruh dunia. Hal ini menjadikan bahasa Jawa sebagai bahasa yang paling sering digunakan di urutan ke-26 dunia (Ethnologue, 2021). Berdasarkan fakta tersebut, bahasa Jawa dipilih dalam penelitian ini karena memiliki daya tarik kepada orang lain untuk dipelajari. Selain itu, membuat dan membaca dokumen berbahasa Jawa merupakan salah satu cara melestarikan penggunaan bahasa Jawa.

Bahasa Jawa memiliki aksen, dialek, intonasi, dan diksi yang kuat dan unik. Secara umum, bahasa Jawa diucapkan dengan jelas, tegas, dengan intonasi pendek dan penekanan di beberapa bagian (Wardani \& Suwartono, 2019). Dalam penerapannya, terdapat tiga dialek utama bahasa Jawa yang saling mempunyai keterkaitan (Oakes, 2016). Dialek daerah Solo dan Yogyakarta, pusat sejarah budaya Jawa, disebut Kejawen, dan dianggap sebagai bentuk standar bahasa Jawa. Bahasa Jawa Timur dituturkan di Surabaya, Malang dan Pasuran (Gordon Jr, 2005). Sedangkan bahasa Jawa Barat dituturkan di Banten, Cirebon dan Tegal yang banyak dipengaruhi oleh bahasa Sunda. Dalam memahami teks bahasa Jawa banyak kata kata yang tidak penting yang berpengaruh dalam kalimat/bacaan. Oleh karena itu, perlu mengurangi jumlah kata dalam sebuah dokumen yang nantinya akan berpengaruh dalam kecepatan dan performa atau biasa disebut dengan stopword removal. Maka diperlukan database stopword yang baik yang digunakan pada proses stopword removal ini.

Algoritma stopword removal dalam sistem Information Retrival, merupakan proses penghapusan semua kata yang tidak memiliki makna (Manning et al., 2009). Dengan kata lain sebuah proses untuk menghilangkan kata yang 'tidak relevan' pada hasil parsing sebuah dokumen teks dengan membandingkannya dengan Stoplist (Stopword List) yang ada (Budhi et al., 2006). Proses pengelompokkan dapat dilakukan dengan mengimplementasikan metode clustering. K-means telah digunakan untuk membentuk stopword bahasa Jawa. Akurasi yang dihasilkan dari metode ini adalah 78,28\% (Wibawa et al., 2020). Penelitian ini bertujuan untuk menerapkan $K$-medoids sebagai alternative pembuatan stopwordlist bahasa Jawa berbasis klastering. Metode ini dipilih karena performa yang lebih kuat terhadap noise dan outlier dibandingkan dengan k-means pada penelitian sebelumnya. Hal ini dikarenakan metode $K$ medoids meminimalkan jumlah ketidakmiripan berpasangan umum daripada jumlah jarak Euclidean kuadrat. Selain itu, metode ini dipilih karena berbagai kelebihannya antara lain: kecepatan komputasi (Velmurugan, 2010), bebas dari pengaruh outlier (Madhulatha, 2011).

\section{LANDASAN TEORI}

Clustering atau klaterisasi adalah metode pengelompolan data. Clustering adalah sebuah proses untuk mengelompokan data ke dalam beberapa cluster atau kelompok, sehingga data dalam satu cluster memiliki tingkat kemiripan yang maksimum dan data antar cluster memiliki kemiripan yang minimum (Tan et al., 2006). Metode untuk melakukan clustering dapat dikategorikan menjadi empat metode, yaitu: partitioning, hierarchical, grid-based and modelbased. Clustering berbasis partitioning menghasilkan partisi dari data sehingga objek dalam cluster lebih mirip satu sama lain daripada objek yang ada dalam cluster lain. K-means dan $K$ medoids adalah contoh dari metode partitioning (Triyanto, 2015). 
Metode $K$-medoids merupakan metode clustering yang berfungsi untuk memecah dataset menjadi kelompok-kelompok. Kelebihan dari metode ini mampu mengatasi kelemahan dari metode K-Means yang sensitive terhadap outlier (Pramesti et al., 2017). K-medoids atau Partitioning Around Medoids (PAM) adalah algoritma clustering yang mirip dengan $K$-means. Perbedaan dari kedua algoritma ini yaitu algoritma $K$-Medoids atau PAM menggunakan objek sebagai perwakilan (medoid) sebagai pusat cluster untuk setiap cluster, sedangkan $K$-means menggunakan nilai rata-rata (mean) sebagai pusat cluster (Madhulatha, 2011). Algoritma $K$ medoids memiliki kelebihan untuk mengatasi kelemahan pada algoritma K-means yang sensitive terhadap noise dan outlier, dimana objek dengan nilai yang besar yang memungkinkan menyimpang dari distribusi data. Kelebihan lainnya yaitu hasil proses clustering ini tidak bergantung pada urutan masuk dataset (Pramesti et al., 2017).

\section{METODE PENELITIAN}

Studi ini menggunakan pendekatan penelitian terapan untuk mengetahui kinerja algoritma K-medoids untuk clustering. Pendekatan penelitian terapan ini dipilih karena bertujuan untuk mencari solusi, dalam kasus ini adalah pembentukan database stopword Bahasa Jawa. Penelitian ini terdiri dari lima tahapan penelitian. Tahapan penelitian ditunjukkan pada gambar 1.

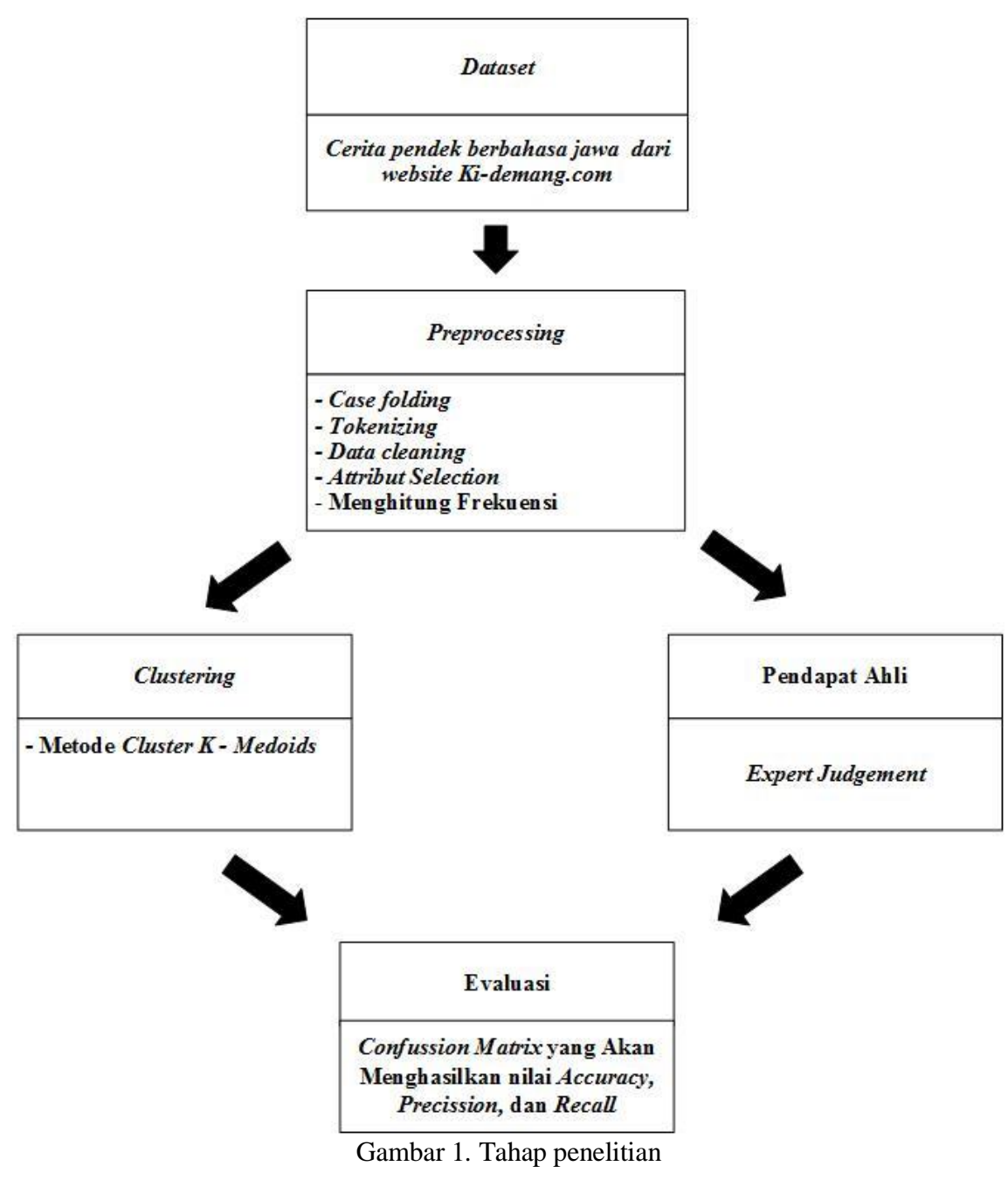

Tahap pertama dimulai dengan pengambilan dataset yang digunakan sebagai input dalam penelitian, dataset diambil dari situs www.ki-demang.com dengan kategori Cerita Pendek 
berbahasa Jawa berjumlah 106 cerita. Cerita yang diambil adalah isi cerita tanpa nomor dan judul. Kumpulan cerita tersebut digabung menjadi satu dokumen teks. Dokumen teks ini yang akan digunakan sebagai dataset penelitian.

Tahap kedua dilakukan proses preprocessing, tahap preprocessing pertama yang dilakukan adalah case folding yaitu tahapan yang mengubah semua huruf dalam dokumen menjadi huruf kecil (Amalia et al., 2018). Hanya huruf 'a' sampai dengan ' $z$ ' yang diterima. Kemudian menghilangkan karakter tanda baca dan angka pada dataset. Selain itu, data akan dibersihkan dari kata yan salah tulis, tidak memiliki makna, nama orang, dan kata yang menggunakan selain bahasa Jawa.

Tahap ketiga, menghitung kata dengan jumlah frekuensi yang terdapat pada dataset dan attribut selection untuk menentukan atribut yang paling berpengaruh dan akan digunakan untuk cluster. Dataset kemudian akan diserahkan ke ahli bahasa Jawa. Ahli mengelompokkan dataset tersebut menjadi dua kelas yaitu kata umum dan kata khusus. Kata umum yaitu kata yang dianggap tidak memiliki makna, seperti kata tambahan dan kata hubung. Sedangkan kata khusus adalah kata yang memiliki makna seperti kata kerja.

Tahap keempat adalah Clustering yang dilakukan untuk mengelompokkan berdasarkan frekuensi setiap jenis kata menggunakan metode $K$-Medoids. Tahapan dari proses clustering ini dapat dilihat pada Gambar 2.

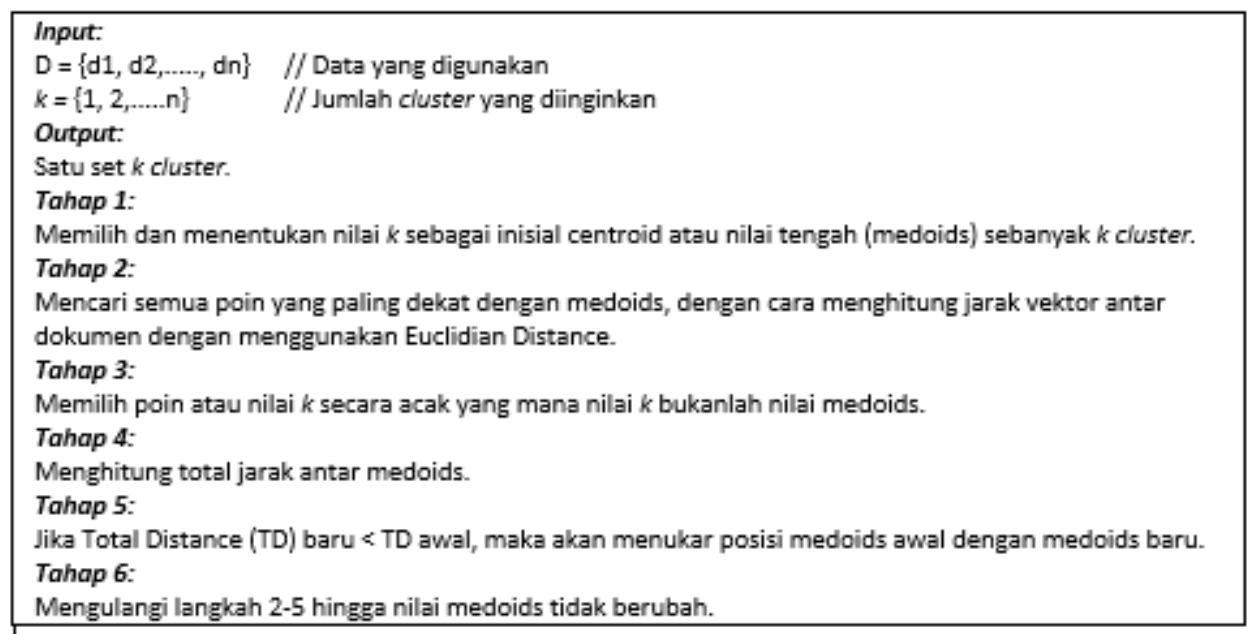

Gambar 2. Tahapan K-Medoids Clustering

Berdasarkan gambar 2, salah satu tahapan K-Medoids Clustering adalah menentukan nilai $k$ atau jumlah cluster, pada penelitian ini nilai $k$ yang digunakan adalah $3,5,7,9,11,13,15,17,19,21,23,25$ dengan metode pemilihan random yaitu nilai $k$ ditentukan tanpa menggunakan perhitungan khusus.

Tahap kelima adalah evaluasi. Evaluasi bertujuan untuk menguji ketepatan hasil clustering dengan metode yang digunakan sehingga dapat diketahui cluster mana yang memiliki stopword terbaik (Ramadhani \& Januarita AK, 2019), mendekati identifikasi pakar. Dalam penelitian ini pendapat ahli bahasa Jawa dianggap mutlak kebenarannya dalam memberikan kelas pada dataset. Setiap hasil clustering akan diuji dengan data ahli untuk evaluasi. Evaluasi dilakukan dengan menggunakan Confussion Matrix. Pengukuran terhadap kinerja suatu sistem klasifikasi merupakan hal yang penting. Kinerja sistem klasifikasi menggambarkan seberapa baik sistem dalam mengklasifikasikan data. Confussion matrix merupakan salah satu metode yang dapat digunakan untuk mengukur kinerja suatu metode klasifikasi. Pada dasarnya confussion matrix mengandung informasi yang membandingkan 
hasil klasifikasi yang dilakukan oleh sistem dengan hasil klasifikasi yang seharusnya (Zayuka et al., 2017).

Pada tahapan ini akan dilakukan uji keakurasian dari algoritma yang digunakan untuk clustering dataset tersebut. Pengujian dilakukan dengan menggunakan parameter berikut.

\begin{abstract}
Akurasi
Akurasi adalah perbandingan data yang diidentifikasi benar dengan jumlah semua data. Dalam penelitian ini nilai akurasi metode didapatkan dengan membagi jumlah dokumen benar bernilai true dengan jumlah semua dokumen yang diklasifikasikan. Nilai true berarti apabila hasil clustering menyatakan bahwa suatu kata adalah stopword dan pada hasil ahli kata tersebut memang stopword, begitu pula untuk kata non stopword.
\end{abstract}

\title{
Presisi
}

Presisi adalah tingkat ketepatan antara data yang diminta dengan jawaban yang diberikan oleh sistem. Perhitungan rasio jumlah data dalam dataset yang benar bernilai true positive terhadap jumlah data true positive dan jumlah data false negative. Nilai true positive berarti hasil clustering menyatakan bahwa suatu kata adalah stopword dan pada hasil ahli kata tersebut memang stopword sedangkan false negative berarti hasil clustering menyatakan bahwa suatu kata adalah stopword akan tetapi pada hasil ahli kata tersebut termasuk nonstopword.

\section{PEMBAHASAN}

Berdasarkan metode yang telah dijelaskan pada bagian sebelumnya, dataset yang digunakan dalam penelitian merupakan 106 cerita pendek dari situs www.ki-demang.com. Setelah semua dataset terkumpul, dilanjutkan pada tahap kedua yaitu preprocessing. Pada tahap kedua ini, dataset dipotong per kata (token) sehingga menghasilkan 17.763 jenis kata dan frekuensinya. Data hasil token tersebut dibersihkan dari kata yang salah tulis, kata tidak memiliki makna, nama orang dan kata yang menggunakan bahasa Jawa selain Ngoko seperti bahasa Indonesia, bahasa Inggris dan bahasa Jawa Krama dihapus, sehingga menjadi 14.384 jenis. Penghapusan ini berdasarkan kamus terjemahan Jawa-Indonesia dan Indonesia-Jawa. Contoh kata yang dihapus dapat dilihat pada tabel 1 .

Tabel 1.

Contoh Kata Yang Dihapus Dalam Tahap Preprocessing

\begin{tabular}{|c|c|c|c|}
\hline Kata salah tulis & $\begin{array}{l}\text { Kata tidak } \\
\text { bermakna }\end{array}$ & Nama Orang & Kata selain Ngoko \\
\hline sepiraa & met & Ezza & Inbox \\
\hline rilaaaaa & We & Siti & Out \\
\hline ewoesemono & Rin & Laras & Awalnya \\
\hline ngetikkkkkk & ooh & Irvan & Apabila \\
\hline pendhafatran & Loh & Dini & Mouse \\
\hline sept & Srat & Yono & In \\
\hline
\end{tabular}

Pada tahap ketiga, dataset yang berjumlah 14.384 jenis kata diserahkan ke ahli bahasa Jawa. Ahli mengelompokkan dataset tersebut menjadi dua kelas yaitu kata umum dan kata khusus. Kata umum yaitu kata yang dianggap tidak memiliki makna, seperti kata tambahan dan kata hubung. Sedangkan kata khusus adalah kata yang memiliki makna seperti kata kerja. Selanjutnya kata umum dianggap sebagai stopword berjumlah 3224 jenis kata dan kata khusus dianggap sebagai non stopword berjumlah 11160. Hasil klasifikasi dari ahli kata dapat dilihat pada tabel 2 . 
Tabel 2.

Contoh Kata Hasil Klasifikasi Dari Ahli Bahasa Jawa

\begin{tabular}{ll}
\hline Stopword & Non Stopword \\
\hline Abdine & Abang \\
Abote & Alasane \\
Apa & Beritane \\
Iki & Karal \\
Jan & Dandang \\
Jane & Kawin \\
\hline
\end{tabular}

Pada tahap keempat, data yang dicluster berjumlah 14.384 jenis kata dan frekuensinya. pada penelitian ini nilai $k$ yang digunakan adalah 3,5,7,9,11,13,15,17,19,21,23,25 dengan metode pemilihan random yaitu nilai $k$ ditentukan tanpa menggunakan perhitungan khusus. Hasil setiap cluster akan dikecilkan menjadi 2 kelas, yaitu kelas stopword dan kelas non stopword. Kelas non stopword adalah seluruh kata pada kelas yang mempunyai nilai anggota tertinggi di setiap cluster nya. Sedangkan kelas stopword adalah seluruh kata pada kelas yang mempunyai nilai anggota lebih rendah dari kelas non stopword. Sebagai contoh pada $k=19$, yang dianggap non stopword adalah $k l$ karena mempunyai nilai anggota yang paling tinggi, sedangkan stopword adalah $k 0,2,3,4,7,9,11,13,17$ karena nilai $k$ tersebut lebih rendah dari $k 1$, seperti gambar 3 .

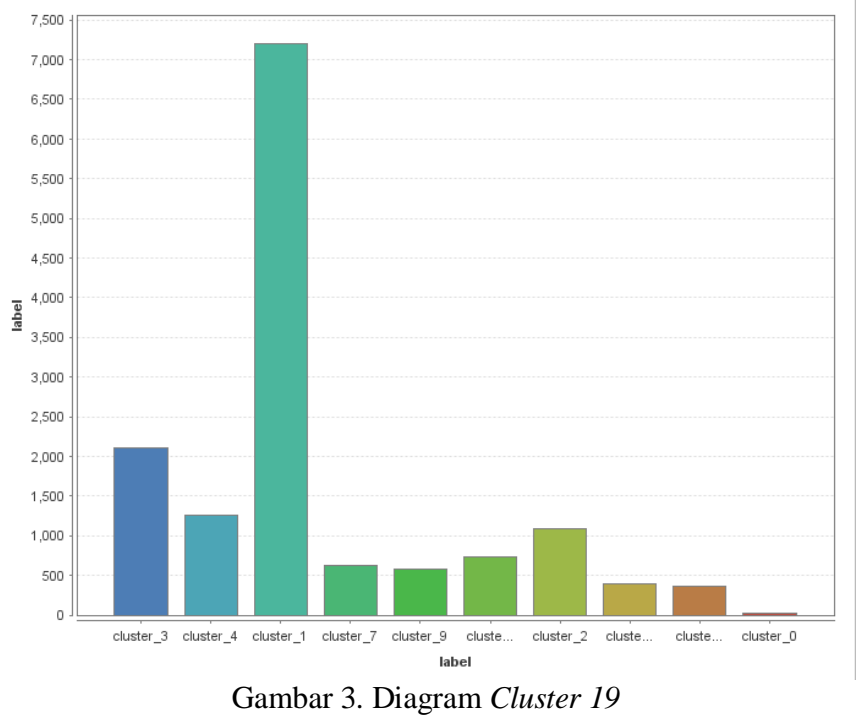

Kemudian pada tahap terakhir yaitu evaluasi. Berdasarkan tahapan penelitian yang telah dilakukan, evaluasi dilaporkan menggunakan confusion matrix berdasarkan data uji yang telah di tentukan dengan mencocokkan stopword dan non stopword hasil clustering dengan stopword dan non stopword milik ahli didapatkan hasil perhitungan seperti pada tabel 3 .

Tabel 3.

Hasil Cluster Stopword dengan Berbagai Nilai K

\begin{tabular}{ccccc}
\hline $\mathbf{k}$ & Akurasi & Presisi & Stopword & Non Stopword \\
\hline $\mathbf{3}$ & $70 \%$ & $69,9 \%$ & 3811 & 10572 \\
$\mathbf{5}$ & $68,9 \%$ & $69 \%$ & 3811 & 10572 \\
$\mathbf{7}$ & $70,4 \%$ & $70,4 \%$ & 3811 & 10572 \\
$\mathbf{9}$ & $68,8 \%$ & $69,9 \%$ & 7118 & 7205 \\
$\mathbf{1 1}$ & $69,1 \%$ & $68,8 \%$ & 7118 & 7205 \\
$\mathbf{1 3}$ & $70,5 \%$ & $70,2 \%$ & 7118 & 7205 \\
$\mathbf{1 5}$ & $69 \%$ & $68,7 \%$ & 7118 & 7205 \\
$\mathbf{1 7}$ & $68,8 \%$ & $68,5 \%$ & 7178 & 7205 \\
$\mathbf{1 9}$ & $69.1 \%$ & $68,7 \%$ & 7178 & 7205 \\
$\mathbf{2 1}$ & $69 \%$ & $68,7 \%$ & 7178 & 7205 \\
$\mathbf{2 3}$ & $68,8 \%$ & $68,5 \%$ & 7178 & 7205 \\
$\mathbf{2 5}$ & $51,3 \%$ & $81,2 \%$ & 7178 & 7205 \\
\hline
\end{tabular}


Pada tabel 3 diketahui akurasi tertinggi adalah 70,5\% dengan presisi 70,2\% yang dimiliki cluster dengan nilai $\mathrm{K}=13$, pada $\mathrm{K}$ tersebut stopword berjumlah 7118 kata. Evaluasi didapat dengan mencocokkan stopword milik ahli yang berjumlah 3224 kata terhadap data uji (data testing) berupa teks berita berbahasa jawa yang berjumlah 387 kata. Diinisialisasikan bahwa true positive merupakan kata yang menurut ahli benar dan hasil cluster benar (benar stopword), false positive merupakan kata yang menurut ahli salah tetapi hasil cluster benar, false negative merupakan kata yang menurut ahli benar tetapi hasil cluster salah, true negative merupakan kata yang menurut ahli salah dan hasil cluster juga salah (bukan stopword) pada data uji.

Berdasarkan tahapan penelitian yang telah dilakukan, hasil perhitungan dengan Confussion Matrix terdapat pada tabel 3. Pada tabel ini sudah diketahui nilai TP (True Positive), FP (False Negative), TN (True Negative) dan FN (False Negative).

Tabel 4.

Hasil Perhitungan Confussion Matrix

\begin{tabular}{lcccclll}
\hline $\boldsymbol{K}$ & TP & FP & TN & FN & Akurasi & Presisi & Recall \\
\hline 3 & 212 & 91 & 17 & 7 & $70 \%$ & $69,9 \%$ & $96,8 \%$ \\
5 & 210 & 94 & 17 & 8 & $68,9 \%$ & $69 \%$ & $96,3 \%$ \\
7 & 215 & 90 & 16 & 7 & $70,4 \%$ & $70,4 \%$ & $96,8 \%$ \\
9 & 219 & 99 & 8 & 4 & $68,8 \%$ & $69,9 \%$ & $98,2 \%$ \\
11 & 218 & 99 & 8 & 2 & $69,1 \%$ & $68,8 \%$ & $99 \%$ \\
13 & 224 & 95 & 8 & 2 & $70,5 \%$ & $70,2 \%$ & $99,1 \%$ \\
15 & 217 & 99 & 8 & 2 & $69 \%$ & $68,7 \%$ & $99 \%$ \\
17 & 217 & 100 & 8 & 2 & $68,8 \%$ & $68,5 \%$ & $99,1 \%$ \\
19 & 217 & 99 & 9 & 2 & $69.1 \%$ & $68,7 \%$ & $99 \%$ \\
21 & 217 & 99 & 8 & 2 & $69 \%$ & $68,7 \%$ & $99 \%$ \\
23 & 217 & 100 & 8 & 2 & $68,8 \%$ & $68,5 \%$ & $99 \%$ \\
25 & 82 & 19 & 80 & 135 & $51,3 \%$ & $81,2 \%$ & $37,8 \%$ \\
\hline
\end{tabular}

Pada tabel 4, hasil akurasi tertinggi pada cluster dengan nilai $\mathrm{K}=13$ dengan nilai akurasi sebesar 70,5\% dan nilai presisi sebesar 70,2\%. Nilai akurasi didapat dari 224 kata bernilai true positive ditambah 8 kata bernilai true negative dibagi dengan 329 kata yang didapatkan dari jumlah nilai pada setiap cell pada confusion matrix $(\mathrm{TP}+\mathrm{FP}+\mathrm{FN}+\mathrm{TN})$. Nilai presisi didapat dari 224 kata bernilai true positive yang dibagi dengan 224 kata bernilai true positive itu sendiri ditambah dengan 95 kata bernilai false positive.

Hasil akurasi terendah terdapat pada cluster dengan nilai $\mathrm{K}=25$ dengan nilai akurasi sebesar 51,3\% dan nilai presisi sebesar $81,2 \%$. Nilai akurasi didapat dari 82 kata bernilai true positive ditambah 80 kata bernilai true negative dibagi dengan 316 kata yang didapatkan dari jumlah nilai pada setiap cell pada confusion matrix $(\mathrm{TP}+\mathrm{FP}+\mathrm{FN}+\mathrm{TN})$. Nilai presisi didapat dari 82 kata bernilai true positive yang dibagi dengan 82 kata bernilai true positive itu sendiri ditambah dengan 19 kata bernilai false positive.

Hasil peneltian menggunakan metode $K$-medoids lebih ideal dibandingkan dengan metode $K$-means yang digunakan dalam penelitian sebelumnya. Hal ini dikarenakan $K$ Medoids mempunyai kinerja lebih kuat dibandingkan dengan $K$-Means. Dalam $K$-Medoids, $\mathrm{k}$ digunakan sebagai objek representatif untuk meminimalkan jumlah ketidaksamaan objek data sedangkan, K-Means menggunakan jumlah jarak Euclidean kuadrat untuk objek data. metrik jarak ini mengurangi noise dan outlier. Namun, dalam penerapannya perlu adanya sumber teks yang lebih banyak. Hal ini digunakan untuk meningkatkan akurasi dalam proses clustering. Pembentukan stopword bahasa Jawa dapat digunakan untuk mengembangkan beberapa aplikasi bidang bahasa khususnya yang berbentuk teks antara lain: klasifikasi genre (Muslimah et al., 2018), analisis sentimen (Hayuningtyas \& Sari, 2019), dan klasifikasi jenis bahasa(Nursirwan, 2012). Dampak pengembangan yang lain adalah mempekaya khasanah pelestarian bahasa dan satra daerah melalui teknologi. Harapannya, generasi muda yang akrab dengan teknologi akan 
semakin mencintai budayanya karena budaya yang bersifat tradisional dapat berasimilasi dengan teknologi.

\section{PENUTUP}

Berdasarkan penelitian yang telah dilakukan mengenai penerapan metode $K$-medoids Clustering pada pembuatan stoplist bahasa Jawa berdasarkan kemunculan kata dalam teks berbahasa Jawa dilakukan dengan beberapa tahapan antara lain, scraping, case folding, tokenizing, data cleaning, perhitungan frekuensi dan atribut selection dapat disimpulkan bahwa metode K-medoids mampu digunakan untuk pembentukan stopword list (stoplist) berbahasa Jawa. Penelitian ini menghasilkan nilai akurasi sebesar 70,5\% yang berada pada cluster dengan nilai $\mathrm{K}=13$, sehingga stopword pada $\mathrm{K}=13$ dipilih untuk membentuk stoplist dikarenakan kebenarannya mendekati stopword yang ditentuka oleh ahli bahasa Jawa. Kedepan, perlu dibuat sopword bahasa Jawa dengan jumlah sumber teks yang lebih banyak, sehingga hasilnya dapat digunakan untuk menunjang pengembangan aplikasi yang terkait pelestarian bahsa dan sastra daerah. Selain itu perlu juga diaplikasikan pada bahasa daerah yang lain untuk mengukur akurasi dan mengetahui apakah karakteristik dari bahasa tersebut bisa digunakan dengan metode yang sama.

\section{DAFTAR PUSTAKA}

Amalia, A., Lydia, M. S., Fadilla, S. D., \& Huda, M. (2018). Perbandingan Metode Klaster dan Preprocessing Untuk Dokumen Berbahasa Indonesia. Jurnal Rekayasa Elektrika, 14(1), 35-42. https://doi.org/10.17529//ire.v14i1.9027

Budhi, G. S., Gunawan, I., \& Yuwono, F. (2006). Algoritma Porter Stemmer For Bahasa Indonesia Untuk Pre-Processing Text Mining Berbasis Metode Market Basket Analysis. PAKAR Jurnal Teknologi Informasi dan Bisnis, 7(3).

Ethnologue. (2021). What are the top 200 most spoken languages? Ethnologue Languages of the World. https://www.ethnologue.com/guides/ethnologue200

Gordon Jr, R. G. (2005). Ethnologue, languages of the world. SIL International.

Hayuningtyas, R. Y., \& Sari, R. (2019). Analisis Sentimen Opini Publik Bahasa Indonesia terhadap Wisata TMII Menggunakan Naïve Bayes dan PSO. Jurnal Techno Nusa Mandiri, 16(1), 37-42. https://doi.org/10.33480/techno.v16i1.115

Kridalaksana, H. (2001). Wiwara: pengantar bahasa dan kebudayaan Jawa. Gramedia Pustaka Utama. Madhulatha, T. S. (2011). Comparison between K-Means and K-Medoids Clustering Algorithms. In D. C. Wyld, M. Wozniak, N. Chaki, N. Meghanathan, \& D. Nagamalai (Eds.), Advances in Computing and Information Technology (pp. 472-481). Springer. https://doi.org/10.1007/9783-642-22555-0 48

Manning, C., Nayak, P., \& Raghavan, P. (2009). Introduction to Information Retrieval: Probabilistic information retrieval. https://doi.org/10.1017/CBO9780511809071

Muslimah, N., Indriati, I., \& Wihandika, R. C. (2018). Klasifikasi Film Berdasarkan Sinopsis dengan Menggunakan Improved K-Nearest Neighbor (K-NN). Jurnal Pengembangan Teknologi Informasi dan Ilmu Komputer, 3(1), 196-204.

Nursirwan, N. (2012). Klasifikasi Leksikostatistik Bahasa Melayu Langkat, Bahasa Melayu Deli, Dan Bahasa Dairi Pakpak. Fakultas Ilmu Budaya Universitas, 10.

Oakes, M. P. (2016). Javanese. In B. Comrie (Ed.), The World's Major Languages (p. 14). Routledge. https://doi.org/10.4324/9781315084862-76

Pramesti, D. F., Furqon, M. T., \& Dewi, C. (2017). Implementasi Metode K-Medoids Clustering Untuk Pengelompokan Data Potensi Kebakaran Hutan/Lahan Berdasarkan Persebaran Titik Panas (Hotspot). Jurnal Pengembangan Teknologi Informasi dan Ilmu Komputer E-ISSN, 1(9), 723732.

Ramadhani, R. D., \& Januarita AK, D. (2019). Evaluasi K-Means dan K-Medoids pada Dataset Kecil. SNIA (Seminar Nasional Informatika dan Aplikasinya).

Saddhono, K., \& Hartanto, W. (2021). A dialect geography in Yogyakarta-Surakarta isolect in Wedi 
District: An examination of permutation and phonological dialectometry as an endeavor to preserve Javanese language in Indonesia. Heliyon, 7(7), e07660. https://doi.org/10.1016/..heliyon.2021.e07660

Tan, P. N., Steinbach, M., \& Kumar, V. (2006). Introduction to Data Mining. Pearson.

Triyanto, W. A. (2015). Algoritma K-Medoids Untuk Penentuan Strategi Pemasaran Produk. Simetris: Jurnal Teknik Mesin, Elektro Dan Ilmu Komputer, 6(1), 183-188. https://doi.org/10.24176/simet.v6i1.254

Velmurugan. (2010). Computational Complexity between K-Means and K-Medoids Clustering Algorithms for Normal and Uniform Distributions of Data Points. Journal of Computer Science, 6(3), 363-368. https://doi.org/10.3844/jcssp.2010.363.368

Wardani, N. A., \& Suwartono, T. (2019). Javanese Language Interference in the Pronunciation of English Phonemes. Celtic: A Journal of Culture, English Language Teaching, Literature and Linguistics, 6(2), 14-25. https://doi.org/10.22219/celtic.v6i2.8589

Wibawa, A. P., Fithri, H. K., Zaeni, I. A. E., \& Nafalski, A. (2020). Generating Javanese Stopwords List using K-means Clustering Algorithm. Knowledge Engineering and Data Science, 3(2), 106. https://doi.org/10.17977/um018v3i22020p106-111

Zayuka, H., Nasution, S. M., \& Purwanto, Y. (2017). Perancangan Dan Analisis Clustering Data Menggunakan K-medoids Untuk Berita Berbahasa Inggris. EProceedings of Engineering, 4(2). 